\title{
Attitude and Perception of Intimate Partner Violence among Women in Military and Civilian Communities in Abuja Nigeria
}

\author{
Uzoamaka Carol Chimah', Prosper Obunikem Uchechukwu Adogu2*, \\ Chika Florence Ubajaka², Amobi Linus Ilika ${ }^{2}$, Nonye Bibiana Egenti ${ }^{3}$ \\ ${ }^{1}$ Medical Department, Ministry of Defence Headquarters, Abuja, Nigeria \\ ${ }^{2}$ Department of Community Medicine and PHC, Nnamdi Azikiwe University/Nnamdi Azikiwe University \\ Teaching Hospital, Nnewi, Nigeria \\ ${ }^{3}$ Department of Community Medicine, University of Abuja, Abuja, Nigeria \\ Email: ${ }^{*}$ prosuperhealth50@gmail.com
}

Received 19 May 2015; accepted 16 June 2015; published 19 June 2015

Copyright @ 2015 by authors and Scientific Research Publishing Inc.

This work is licensed under the Creative Commons Attribution International License (CC BY).

http://creativecommons.org/licenses/by/4.0/

c) (†) Open Access

\begin{abstract}
This was a descriptive comparative study of attitude towards intimate partner violence (IPV) involving 260 female intimate partners of military and civilian men in Abuja, Nigeria. More civilian respondents than the military believed in total submission of a wife to her husband's views ( $p=$ $0.000)$, frowned at wife beating $(p=0.000)$, supported sexual assertiveness by women $(p=0.006)$ and believed that a wife should satisfy her partner sexually, $(p=0.000)$. More military respondents than civilians preferred family matters to be kept confidential $(p=0.000)$. Addressing IPV requires immediate and long term commitment and strategies to the attitude of both the women and their husbands.
\end{abstract}

\section{Keywords}

Attitude, Intimate Partner Violence, Women, Military, Civilian, Nigeria

\section{Introduction}

In many cultures, women share the notion that men have the right to discipline their wives by using force. The circumstances under which women believed that a man was justified in beating his wife and women's beliefs about whether and when a woman may refuse to have sex with her husband were explored by World Health Or-

"Corresponding author.

How to cite this paper: Chimah, U. C., Adogu, P. O. U., Ubajaka, C. F., Ilika, A. L., \& Egenti, N. B. (2015). Attitude and Perception of Intimate Partner Violence among Women in Military and Civilian Communities in Abuja Nigeria. Advances in Applied Sociology, 5, 195-205. http://dx.doi.org/10.4236/aasoci.2015.56019 
ganization Multi-Center Study (WHOMCS) (World Health Organization, 2005). The study reported wide variation in women's agreement with reasons for justifying violence. The most marked variation was between the urban, industrialized settings and the rural and traditional ones. In rural Egypt for example, at least $80 \%$ of women said that beatings were justified under certain circumstances and one of the circumstances women themselves cited was refusing a male partner sex (Ellsberg et al., 1999; Thurston et al., 2006). While over three quarters of women in the urban settings of Brazil, Japan, Namibia, Serbia and Montenegro said that no reason justifies violence, at most only a quarter thought so in the provincial settings of Bangladesh, Ethiopia, Peru, and Samoa. In all settings, the reason most widely accepted as justification for violence was female infidelity, but the range was wide from 6\% in Serbia and Montenegro city to $80 \%$ in the provinces of Bangladesh, Ethiopia, Peru and Samoa, Thailand and United Republic of Tanzania. Disobeying, a husband was the next most accepted reason (Hurwitz et al., 2006; Subramaniam et al., 2001).

In virtually all cases and for all reasons, acceptance of wife-beating was higher among women who had experienced abuse than among those who had not. This may indicate that women learn to "accept" violence in circumstances where they themselves are victims, or that women who see violence as "normal" are more likely to enter or remain in violent relationships (World Health Organization, 2005). Similarly, in a study in Zimbabwe, over $50 \%$ of women believed that wife beating was justified under the following circumstances, if a wife argued with husband (36\%), neglected her children (33\%) or went out without husband's permission (30\%) (Hindin et al., 2003), while in Uganda, 90\% of women justified wife beating under various circumstances (Ilika et al., 2005).

As with wife beating, women made distinctions as to what are acceptable reasons for a woman to refuse unwanted sexual demand from an intimate partner, including if she is sick, if she does not want to have sex, if the husband is drunk, and if the husband is mistreating her. As with physical violence, women appeared to make distinctions between the acceptability of different reasons to refuse sex. Fewer women felt sex could be refused based on a woman's preference (she doesn't want it) than if she was ill or the partner was drunk or abusive. In the provincial sites of Bangladesh, Peru, United Republic of Tanzania, Ethiopia and Samoa, between 10\% and $20 \%$ of women felt that women did not have the right to refuse to have sex with their partners under any circumstances (World Health Organization, 2005). In Eastern Nigeria, findings revealed that the women generally condoned and were complacent with intimate partner violence, perceiving it as cultural and religious norms. The women felt that reprimands, beating and forced sex affecting their physical, mental and reproductive wellbeing are normal in marriage. They did not support reporting such cases to the police or divorcing the man, they would rather prefer reporting to family members (Ilika et al., 2005).

In the same vein, majority of victims of intimate partner violence among military couples are females. Certain military culture and lifestyle have a strong hand in shaping their experiences, as well as making the female partners extremely vulnerable to the consequences of partner abuse (Harrison, 2002). Added to their unique vulnerability to intimate partner violence (IPV), the military female partner also faces the potential negative consequences of isolation, secretiveness and dependability which characterize the military career (Stamm, 2009). For many military members, their job is more than just a career; it is their identity (Stamm, 2009). For example if it is found out that a military personnel has committed an act of violence against a family member, the personnel may be discharged from the army thereby losing his military title, employment and family income. This loss of identity can lead to higher risks of violence against his female partner because of the feeling of despondency that is associated with a truncated career (Stamm, 2009).

Thus the study hypothesis states that the nature of the military profession is likely to impact negatively on the way they relate with and treat their female intimate partners when compared with their civilian counterparts.

The objective of this study is to determine and compare the attitudes of the respondents towards IPV in military and civilian communities in Federal Capital Territory (FCT), Abuja, Nigeria.

\section{Methodology}

The study was carried out in Abuja Municipal Area Council (AMAC) and the design was descriptive cross sectional and comparative study.

The study population comprised of females who were in intimate relationship with the male heads of the households in Lungi military barrack and civilian community zone 2, Wuse, Abuja.

Inclusion criterion was female intimate partners of the head of the households, who were either married, and living together for at least six months or unmarried but cohabiting for at least six months. Exclusion criteria 
were female military personnel who were married to civilians and households where both partners were civilians (though living in the barrack). Widows were also excluded in both military and civilian populations.

The minimum sample size (n) for comparison of two independent group proportions was obtained using the appropriate formula (Abby et al., 1995): Also making use of figures 0.81 (proportion of women who experienced physical violence in a studyin a civilian community in Lagos) (Odujurin, 1999) and 0.893 (proportion of women who experienced physical abuse in military population in USA) (Rentz et al., 2006), and providing for $70 \%$ response rate:

$\mathrm{n}$ per group $=109$, giving a minimum sample size of 218 for both groups. However, sample sizes of 130 and 108 were used for military and civilian groups respectively.

Sampling procedure and selection of study location:

AMAC was selected purposively out of the six area councils that make up the Federal Capital Territory because it has a concentration of six barracks. Lungi barrack was selected out of the six barracks by simple cluster random sampling using ballot method while Zone 2, Wuse was purposively selected because it appeared to be the closest in features to the barracks in terms of architectural design and ethnic and religious diversity and the fact that majority of the residents are civil servants of various cadre; the area is a distance of about $8-10 \mathrm{~km}$ away from the barrack location.

A multi-stage sampling technique was used to select 130 female respondents from each of the study populations (Lungi barrack and Zone 2, Wuse).

Sampling from military community (Lungi Barrack):

Stage 1-Selection of blocks: Six blocks were selected out of the existing 18 blocks for "other ranks" by simple ballot method and the only block for officers was selected.

Stage 2-Selection of flats: From a sampling frame of 7 blocks selected using the flat numbering, a total of 266 flats were listed and systematic sampling technique used to select 130 flats at a sampling interval of 2 . Households occupying the selected flats constituted the sampling units.

Stage 3-Selection of respondents: An eligible woman who is the intimate partner of the male head of household in each selected flat was interviewed. Where there were more than one household occupying a flat, only one household was selected by simple balloting and in polygamous households, only one female partner selected by balloting was interviewed.

Sampling from civilian community (Zone 2, Wuse):

Stage 1-Selection of streets: Wuse Zone 2 is made up of 16 streets with an average of 63 houses per street. The streets were stratified into 7 short and 9 long streets and 4 streets were selected from each stratum by simple balloting, giving a total of 8 streets with 268 houses.

Stage 2-Selection of houses: From a sampling frame of 268 houses listed by the house numbering system, 130 houses were selected by systematic sampling method using a sampling interval of 2 . Households occupying the selected houses constituted the sampling units.

Stage 3-Selection of respondents: One eligible intimate partner of a household head was interviewed in each household. Where there was more than one household occupying a house, only one was selected by simple balloting and in polygamous households; only one female partner selected by simple balloting was interviewed.

Data collection tool and technique:

A semi-structured, pre-tested interviewer administered questionnaire was used to collect quantitative data. The questionnaire was adapted from the WHO standardized questionnaire for collection of data on women's health and domestic violence used for the multi-country study (WHOMCS) on women's' health and life experience. The questionnaire consisted of sections on socio-demographic data of the respondents, the characteristics of respondent's current or most recent partner, forms of intimate partner violence and attitude of respondents towards IPV.

Two-day training for the research assistants was conducted using the WHO standard training manual for the WHOMCS study (World Health Organization, 2007). The questionnaire was pre-tested in Sanni Abacha Barracks and Zone 1 Wuse and thereafter corrected to remove areas of ambiguity before the data collection.

The data collection then took place between May and June 2012.Data was analyzed using SPSS and Epi-info 2012. Frequencies, proportions and percentages were generated and continuous variables were expressed as means ( \pm standard deviations). Statistical analysis of difference between proportions was carried out using the Pearson Chi-square and Fischer's exact Chi-square test was used wherever the cell content was less than 5.

Attitude to intimate partner violence were assessed using 3 parameters: 1) attitude to inter-partner relationship, 
2) attitude to wife beating and 3: attitude to sexual assertiveness.

Attitude to inter-partner relationship was assessed using Likert scale, maximum score was 25 and minimum score was 5: (strongly disagree $=5$, strongly agree $=1$ ).

Attitude to wife beating was assessed using eight statements, scores were allotted as follows to the responses, yes $=1$, don't know $=0$, no $=2$. Maximum score $=16$, respondents who scored $<12$ were considered to be supportive of wife beating and so had a negative attitude while respondents with scores $>12$ were considered to be non-supportive of wife beating and so had a "positive attitude". Mean attitude score between the civilian and military population were compared.

Also attitude to sexual assertiveness was assessed using four statements. Scores were allotted to responses as follows: yes $=2$, no $=1$. Maximum score $=8$, respondents who score $>5$ were considered to have positive attitude (i.e., being assertive about their sexual choices) while those who score $<5$ were considered to have negative attitude (not being assertive). The sources from which respondent who have ever experienced IPV sought help was collapsed into in-formal networks (family and friends), formal networks ((police/judiciary, NGOs etc.) and persons in position of authority (religious leaders, traditional rulers etc.) to provide larger figures for meaningful analysis.

The respondents occupations were classified into 3 classes using the socio-economic classification in a United States study (Heyman et al., 1999) and British National Statistics socioeconomic classification (Williamson, 2011), into: Professionals\& skilled (accountants, doctors, secretary, teachers, Nurses etc.), partially skilled (hairdressers, seamstresses, farmers, big-time traders etc.) and unskilled (housewives, petty traders, cleaners, etc.).

Ethical considerations:

Permission for this study was obtained from Research and Ethics Committee of Lagos University Teaching Hospital, Idi-Araba and Federal Capital Territory Authority (Health and Human Development Department Ethics Committee. Also written permission was obtained from the commanding officer of the 7 Guards Battalion, Lungi Barracks as well as obtained from each respondent prior to interview. Verbal consent was obtained from the chairmen of the streets selected for the study before entry into the civilian community.

\section{Discussion}

In Table 1, the female intimate partners of the civilian population are generally older with mean age approximately $38.0 \pm 10.6$ years compared to $30.4 \pm 10.8$ years in the military population $(p=0.000)$. Respondents in

Table 1. Distribution of respondents' socio-demographic characteristics in civilian and military population.

\begin{tabular}{|c|c|c|c|c|c|}
\hline $\begin{array}{l}\text { Socio-demographic } \\
\text { characteristics }\end{array}$ & $\begin{array}{c}\text { Civilian community } \\
\mathrm{N}=108 \\
\mathrm{n}(\%)\end{array}$ & $\begin{array}{c}\text { Military community } \\
\mathrm{N}=130 \\
\mathrm{n}(\%)\end{array}$ & $\begin{array}{c}\text { Total } \\
\mathrm{N}=238 \\
\mathrm{n}(\%)\end{array}$ & Statistics $X^{2}$ & $p$-value \\
\hline \multicolumn{6}{|l|}{ Age group (years) } \\
\hline $15-24$ & $7(6.5)$ & $19(14.6)$ & $26(10.9)$ & & \\
\hline $25-34$ & 37 (34.3) & 83 (63.8) & $120(50.4)$ & 35.53 & $0.000^{*}$ \\
\hline$\geq 35$ & $64(59.2)$ & $28(21.5)$ & 92 (38.7) & & \\
\hline Mean age $( \pm$ S.D) years & $37.97 \pm 10.582$ & $30.44 \pm 10.753$ & & & \\
\hline \multicolumn{6}{|l|}{ Educational status } \\
\hline None & $3(2.8)$ & $5(3.8)$ & $8(3.4)$ & 38.24 & $0.000^{*}$ \\
\hline Primary & $4(3.7)$ & $17(13.1)$ & $21(8.8)$ & & \\
\hline Secondary & $34(31.5)$ & $78(60.0)$ & $112(47.1)$ & & \\
\hline Tertiary & $67(62.0)$ & $30(23.1)$ & $97(40.8)$ & & \\
\hline \multicolumn{6}{|l|}{ Occupation } \\
\hline Professionals \& skilled & 77 (71.3) & $14(5.9)$ & 91 (39.1) & 91.71 & $0.000^{*}$ \\
\hline Partially skilled & $13(12.0)$ & $55(20.2)$ & $68(28.6)$ & & \\
\hline Unskilled & $18(16.7)$ & $61(25.6)$ & 79 (35.3) & & \\
\hline
\end{tabular}


the civilian community are better educated with 67 (62.0\%) attaining tertiary education compared to 30 (23.1\%) in the military population $(p=0.000)$. There are significantly more professional/skilled respondents among civilian women $77(71.3 \%)$ than are found among the military $14(5.9 \%)(p=0.000)$. Thus the civilian respondents are better economically empowered, with $60 \%$ of them earning a monthly income of N30,000 and above, compared to 102 (78.5\%) of the military respondents who earned $<\mathrm{N} 10,000$. This difference is also statistically significant $(p=0.000)$.

In Table 2, significantly more civilian respondents 95 (88.0\%) than their military counterparts 111 (85.4\%), were of the opinion that a wife must always agree with the husband $(p=0.000)$. More military respondents 123 (94.6\%) than the civilians 90 (83.3\%), believed that family matters should be kept within the family $(p=0.000)$. Conversely, significantly more civilian respondents 63 (58.3\%) than the military respondents 67 (51.5\%) supported the view that a man ought to show that he is the boss in the family $(p=0.018)$. More civilian respondents $81(75.1 \%)$ than military $65(50.0 \%)$ were of the opinion that it is a wife's duty to satisfy her partner sexually, and this is significant at $p=0.000$.

Table 3 shows that across the various parameters used to assess women's response to wife beating, majority of the respondents found no justification for wife beating as shown by the proportions of negative responses.

Table 2. Comparison of respondents' self-reported responses to inter-partner relationship in civilian and military population.

\begin{tabular}{|c|c|c|c|c|c|}
\hline Attitude & $\begin{array}{c}\text { Civilian } \\
\mathrm{N}=108 \\
\mathrm{n}(\%)\end{array}$ & $\begin{array}{c}\text { Military } \\
\text { N = } 130 \\
\text { n (\%) }\end{array}$ & $\begin{array}{c}\text { Total } \\
\mathrm{N}=238 \\
\text { n (\%) }\end{array}$ & Statistics $X^{2}$ & $p$-value \\
\hline \multicolumn{6}{|c|}{$\begin{array}{l}\text { A good wife must always agree } \\
\text { with spouse's views }\end{array}$} \\
\hline Agree & 95 (88.0) & $111(85.4)$ & 206 (86.6) & 22.43 & $0.000^{* *}$ \\
\hline Not sure & $5(4.6)$ & $0(0)$ & $5(2.1)$ & & \\
\hline Disagree & $8(7.4)$ & 19 (14.6) & 27 (11.3) & & \\
\hline \multicolumn{6}{|c|}{$\begin{array}{l}\text { Family matters should always } \\
\text { be kept in the family }\end{array}$} \\
\hline Agree & 90 (83.3) & 123 (94.6) & 213 (89.5) & 35.55 & $0.000^{*}$ \\
\hline Not sure & $3(2.8)$ & $0(0)$ & $3(1.2)$ & & \\
\hline Disagree & 15 (13.9) & $7(5.4)$ & $22(9.2)$ & & \\
\hline \multicolumn{6}{|c|}{$\begin{array}{l}\text { A male partner must always } \\
\text { show he is the boss }\end{array}$} \\
\hline Agree & 63 (58.3) & $54(41.5)$ & $117(49.2)$ & 8.06 & $0.018^{*}$ \\
\hline Not sure & $9(8.3)$ & $9(8.3)$ & $18(7.6)$ & & \\
\hline Disagree & 36 (33.4) & $67(51.5)$ & 103 (43.3) & & \\
\hline \multicolumn{6}{|c|}{$\begin{array}{l}\text { A wife must oblige her spouse } \\
\text { sex at his demand }\end{array}$} \\
\hline Agree & $81(75.1)$ & $65(50.0)$ & 146 (61.3) & 18.84 & $0.000^{* *}$ \\
\hline Not sure & $3(2.7)$ & $20(15.4)$ & $23(9.7)$ & & \\
\hline Disagree & $24(22.2)$ & 45 (34.6) & $69(29.0)$ & & \\
\hline \multicolumn{6}{|c|}{$\begin{array}{l}\text { If a man beats his wife, outsiders } \\
\text { should intervene }\end{array}$} \\
\hline Agree & 33 (30.6) & $55(42.3)$ & $88(37.0)$ & 64.00 & $0.00^{*}$ \\
\hline Not sure & $5(4.6)$ & $1(0.8)$ & $6(2.5)$ & & \\
\hline Disagree & 70 (64.8) & 74 (56.9) & $144(60.5)$ & & \\
\hline
\end{tabular}


Table 3. Comparison of reasons for which wife beating was justified by respondents in civilian and military populations.

\begin{tabular}{|c|c|c|c|c|}
\hline Wife beating is justified if & $\begin{array}{c}\text { Civilian } \\
\mathrm{N}=108 \\
\mathrm{n}(\%)\end{array}$ & $\begin{array}{c}\text { Military } \\
\mathrm{N}=130 \\
\text { n (\%) }\end{array}$ & Statistics $\mathrm{X}^{2}$ & $p$-value \\
\hline \multicolumn{5}{|c|}{$\begin{array}{l}\text { She does not complete her household } \\
\text { work to his satisfaction }\end{array}$} \\
\hline Yes & $8(7.4)$ & $23(18.5)$ & 6.454 & $0.040^{*}$ \\
\hline No & $100(92.6)$ & $106(81.5)$ & & \\
\hline Don’t know & $0(0.0)$ & $0(0.0)$ & & \\
\hline \multicolumn{5}{|l|}{ She refuses to obey his instructions } \\
\hline Yes & $9(11.1)$ & $37(28.5)$ & 18.213 & $0.000^{*}$ \\
\hline No & 96 (88.9) & $93(71.5)$ & & \\
\hline Don’t know & $0(0.0)$ & $0(0.0)$ & & \\
\hline \multicolumn{5}{|l|}{$\begin{array}{l}\text { She refuses to have sexual } \\
\text { relations with him }\end{array}$} \\
\hline Yes & $2(7.4)$ & $32(24.6)$ & 30.720 & $0.000^{*}$ \\
\hline No & $100(92.6)$ & $98(75.4)$ & & \\
\hline Don’t know & $0(0.0)$ & $0(0.0)$ & & \\
\hline \multicolumn{5}{|l|}{$\begin{array}{c}\text { She asks him whether he has } \\
\text { other girlfriends }\end{array}$} \\
\hline Yes & $9(8.3)$ & $14(10.8)$ & 1.617 & 0.446 \\
\hline No & $89(82.4)$ & 109 (83.8) & & \\
\hline Don't know & $10(9.3)$ & $7(5.4)$ & & \\
\hline
\end{tabular}

These findings are statistically significant $(p<0.05)$ except in situations where wife asks the husband if he has other girlfriends ( $p=0.446)$, husband suspects the wife of being unfaithful $(p=0.185)$ and wife uses family planning without husband's knowledge $(p=0.060)$.

Table 4 shows that more than half of the women in both populations, 60 (55.5\%) and 100 (76.9\%) for civilian and military respectively, believe that a woman should not deny her partner sexual relationship just because she does not feel like it. The difference in this belief between the two groups is statistically significant $(p=0.000)$. Considering the situation when the man is drunk, the attitude in both civilian and military populations were almost the same as 56 (51.9\%) and 67 (51.5\%) among civilian and military populations respectively said "yes" indicating a positive attitude to deny him sex under that circumstance while 52 (48.1\%) and 63 (48.5\%) said "no", indicating a negative attitude to still let him have his way despite his drunkenness. Also over $60 \%$ of the respondents in the two populations believed a woman should refuse sex when she is sick. However, these differences are not statistically significant $(p>0.05)$.

Table 5 depicts that majority of the respondents in both military 110 (84.6\%) and civilian 99 (91.7\%) populations have negative attitude towards inter-partner relationship (meaning they are not likely to be able to assert their right in a relationship). More women from the military 20 (15.4\%) population have positive attitude 20 (15.4\%) than among civilians 9 (8.3\%). However, these differences are not statistically significant $(p=0.098)$. More civilians have positive attitude 84 (77.8\%), which implies being less tolerant of wife beating compared to a little above half of the military respondents who have negative attitude 72 (55.4\%) towards wife beating (i.e. being supportive of wife beating). This difference in attitude between women in military and civilian population is statistically significant $(p=0.000)$. Significantly greater proportion of women in the civilian community are more sexually assertive 73 (67.6\%) compared to their military counterparts 66 (50.8\%) while nearly half 64 (49.2\%) of the respondents from the military community had negative attitude (not sexually assertive) compared to one-third 35 (32.4\%) of the civilian population who display the same attitude. These findings are statistically significant $p=0.006$. 
Table 4. Comparison of respondents self-reported reasons for refusing sex in civilian and military populations.

\begin{tabular}{|c|c|c|c|c|c|}
\hline A woman can refuse sex if & $\begin{array}{c}\text { Civilian } \\
\mathrm{N}=108 \\
\mathrm{n}(\%)\end{array}$ & $\begin{array}{c}\text { Military } \\
\text { N = 130 } \\
\text { n (\%) }\end{array}$ & $\begin{array}{c}\text { Total } \\
\text { N = 238 } \\
\text { n (\%) }\end{array}$ & Statistics $X^{2}$ & $p$-value \\
\hline \multicolumn{6}{|l|}{ She does not want to } \\
\hline Yes & $48(44.4)$ & $30(23.1)$ & $78(32.8)$ & 12.2 & $0.000^{*}$ \\
\hline No & $60(55.6)$ & 100 (76.9) & $160(67.2)$ & & \\
\hline \multicolumn{6}{|l|}{ Total } \\
\hline \multicolumn{6}{|l|}{ Partner is drunk } \\
\hline Yes & $56(51.9)$ & 67 (51.5) & $123(51.7)$ & 0.00 & 0.962 \\
\hline No & $52(48.1)$ & $63(48.5)$ & $115(48.3)$ & & \\
\hline \multicolumn{6}{|l|}{ She is sick } \\
\hline Yes & $73(67.6)$ & $87(66.9)$ & $160(67.2)$ & 0.01 & 0.913 \\
\hline No & $35(32.4)$ & $43(33.1)$ & $78(32.8)$ & & \\
\hline \multicolumn{6}{|l|}{ He maltreats her } \\
\hline Yes & $61(56.5)$ & $47(36.2)$ & $108(45.4)$ & 2.52 & 0.113 \\
\hline No & $47(43.5)$ & $70(63.8)$ & $117(54.6)$ & & \\
\hline
\end{tabular}

Yes = positive attitude, $\mathrm{No}^{=}$negative attitude.

Table 5. Attitude towards inter-partner relationship, wife beating and sexual assertiveness among civilian and military respondents.

\begin{tabular}{|c|c|c|c|c|c|}
\hline Attitude & $\begin{array}{c}\text { Civilian } \\
\mathrm{N}=108 \\
\mathrm{n}(\%)\end{array}$ & $\begin{array}{c}\text { Military } \\
\text { N = } 130 \\
\text { n (\%) }\end{array}$ & $\begin{array}{c}\text { Total } \\
\mathrm{N}=238 \\
\text { n (\%) }\end{array}$ & $\mathrm{X}^{2}$ & $p$-value \\
\hline \multicolumn{6}{|l|}{ Inter-partner relationship } \\
\hline Positive attitude & $9(8.3)$ & $20(15.4)$ & $29(12.2)$ & 2.471 & 0.098 \\
\hline Negative attitude & 99 (91.7) & $110(84.6)$ & $209(87.8)$ & & \\
\hline \multicolumn{6}{|l|}{ Wife beating } \\
\hline $\begin{array}{c}\text { Positive attitude } \\
\text { (not support wife beating) }\end{array}$ & $84(77.8)$ & $58(44.6)$ & $142(59.7)$ & 26.96 & $0.000^{*}$ \\
\hline $\begin{array}{l}\text { Negative attitude } \\
\text { (supports wife beating) }\end{array}$ & $24(22.2)$ & $72(55.4)$ & $96(40.3)$ & & \\
\hline \multicolumn{6}{|l|}{ Sexual assertiveness } \\
\hline $\begin{array}{l}\text { Positive attitude } \\
\text { (sexually assertive) }\end{array}$ & $73(67.6)$ & $66(50.8)$ & $139(58.4)$ & 6.87 & $0.006^{*}$ \\
\hline $\begin{array}{c}\text { Negative attitude } \\
\text { (not sexually assertive) }\end{array}$ & $35(32.4)$ & $64(49.2)$ & 99 (41.6) & & \\
\hline
\end{tabular}

\section{Discussion}

The attitude of the respondents towards intimate partner relationships leaves much to be desired. Majority of the women in both military and civilian populations tend to have negative attitude towards relationship with partner. They believe that a woman should always agree to the male partner's view even when these run contrary to her conviction and ideology. Granted that this will guarantee peace in the relationship, but it will make the woman gradually loose her personal identity as an individual and suppress her own potentials and rights. Part of the 
reason for this negative attitude has to do with the socialization of the girl child who is often made to believe that she is inferior to the male child (Alabi et al., 2014). This belief is tenaciously held onto by the girl child even up to the point when she enters her matrimonial home with the result that she now becomes subordinated to her male partner. Among the military's female partners, this tendency to agree with every opinion of the husband may be fueled by their low earning power as reported in this study.

This study also exposed the women's belief that family problems should never be discussed with outsiders; a practice that is often canvassed and encouraged among married couples, but which can also portend negative and dangerous consequences among women victims of intimate violence who may prefer to die in silence rather than seek help from outside (Rabb, 2012). This situation invariably encourages the male perpetrator of violence to continue in the dastardly act unchallenged. Again poor economic status especially of the military group is perhaps the reason for their reluctance to involve an outsider in their predicament (Antalupo et al., 2006). They are simply afraid that this may lead to separation or divorce. Once such victims leave the perpetrator of violence; they can be stunned with the reality of the extent to which the abuse has taken away their autonomy. Due to economic abuse and isolation, the victim usually has very little money of their own and few people on whom they can rely when seeking help. This has been shown to be one of the greatest obstacles facing victims of domestic violence and the strongest factor that can discourage them from leaving their perpetrators (Valladares et al., 2005). In addition to lacking financial resources, victims of domestic violence also often lack specialized skills, education and training that are necessary to find gainful employment and also may have several children to support. In 2000, thirty-six major US cities cited domestic violence as one of the primary causes of homelessness in their areas (Ijaden \& Theonnes, 2000). It has also been reported that one out of every three homeless woman is homeless due to having left a domestic violence relationship. If the victim is able to secure rental housing, it is likely that her apartment will have zero tolerance policy for crime; these policies can cause her to be evicted if they are the victim of violence. A victim's overwhelming lack of resources, can lead to homelessness and extreme poverty.

A bossy male partner easily triggers a negative attitude that will encourage violence in a relationship. For example a wife who believes she is obligated to satisfy the sexual needs of her bossy husband at anytime irrespective of her own feeling and safety has a destructive negative attitude. Similarly, respondents in this study disagree to any intervention by neighbors and/or relations when a woman is beaten by her partner. This attitude may appear good on the surface but it has a negative tendency to create a feeling of resignation and to nurture a dangerous culture of silence among IPV victims. This may in turn encourage the perpetrators of violence to eventually destroy the victim. The women from the civilian population display more negative attitude to interpartner relationship (not being able to assert their right in a relationship) compared to those from the military barracks. The regimented nature of the military profession with its attendant disciplined lifestyle and sanctions for any act of indiscipline may have bolstered the confidence of their female partners to assert their rights in the relationship even better than their more educated civilian counterparts (Cone, 2011; Swain, 2010).

Regarding attitude to wife beating, majority of the respondents from both military and civilian populations did not justify wife beating for any reason whatsoever. This is a positive attitude. However few participants believe that a situation where a woman is unfaithful to her partner, wife beating is justified. Some younger women in the military population even believe that wife beating is justified if a woman denies her husband sex under any circumstances. These are however minority views. The reason for the majority view of wide rejection of wife beating may be due to recent media sensitization on the elimination of violence against women thus, many women are beginning to appreciate themselves better and to stand up for their rights. However this finding varies from WHOMCS (World Health Organization, 2005) and a study in Zimbabwe (Hindin et al., 2003) and Uganda (Koenig et al., 2003) which reported wide variation in women's agreement with reasons for justifying wife beating. In rural Egypt for example, $80 \%$ of women said that wife beating is justified under certain circumstances (Egyptian National Demographic and Health Survey, 2005) and one of the circumstances cited was refusing male partner sex. Over three quarters of the urban settings of Brazil, Japan, Namibia, Serbia and Montenegro said no reason justifies (World Health Organization, 2005) wife beating, thus corroborating the finding from this study. In most settings, the widely accepted reason for justification of IPV was female infidelity, but the range was wide from 6\% in Serbia and Montenegro to 80\% in the provinces of Bangladesh, Ethiopia, Peru and Samoa. In Thailand and United Republic of Tanzania, disobeying a husband is the next most accepted reason (World Health Organization, 2005).

Concerning acceptable reasons for a woman to refuse unwanted sexual demands from an intimate partner, in 
this study, women made distinctions between the acceptability of different reasons to refuse sex. Fewer respondents felt that sex could be refused based on a woman's preference (she does not want it) than if she was ill or if the partner was drunk. More than $60 \%$ of women in the military and $43 \%$ from civilian population believed that partner being abusive is not a good reason to refuse sex. The reason for this attitude has to do with the socialization of the girl-child and the patriarchal nature of the Nigerian society that perceives the woman as a sub-human being whose identity and rights are lost in her spouse's once married. These figures are higher than what was obtained from WHOMCS (World Health Organization, 2005) in which only 10\% - 20\% of respondents felt that women did not have the right to deny their intimate partner sex under any circumstances. This also agrees with findings in a study in Eastern Nigeria where women generally condone and are complacent with IPV, perceiving it as cultural and religious norms (Ilika et al., 2005). The women felt that reprimands, beatings and forced sex affecting their mental, physical and reproductive health are normal in marriage (Ilika et al., 2005).

\section{Conclusion}

In conclusion, though majority of women in this study did not justify wife beating under any circumstance, some still believed that there were situations under which wife beating was justified. Women in both study populations have negative attitudes towards exercising their fundamental human right as individuals especially over their bodies and sexual desires and this has negative implications for their physical and reproductive health.

It is therefore recommended that addressing IPV should be multi-sectorial (involving individuals, family, community, health, social services, religious org, judiciary and police, trade unions, businesses and media) and requires immediate and long term commitment and strategies.

At the family level, there should be value re-orientation and discouragement of family norms that promote negative unbalanced patriarchy through health education. Both the male and female child should be given equal opportunities for self-actualization. Practices such as male preference and superior treatment of male child in the family should be discouraged.

Communities should be sensitized through mass media and religious leaders to the fact that IPV is a public health problem and of the urgent need to start addressing the societal norms that drive it, such as our patriarchal systems of socialization and cultural practices which favour the interests of men above those of women. Reaching out to men's groups through advocacy and education to discourage some habits (alcohol, hard drugs, aggression, etc.), attitudes and beliefs that promote abusive behaviours, "the message should be that the abuser of today is a father of the abused tomorrow and sensible and responsible men will not stand their daughters being abused” At the community level, individuals and families should be encouraged and sensitized to the public health importance of eliminating IPV and how this can impact positively on women, children and development. NGOs working in this area should also be encouraged on short term to establish temporary shelters where feasible, provide empowerment programmes and assist victim in seeking legal redress where necessary. The religious communities, since they are important source where IPV victims seek support should be sensitized to be more proactive in preaching against IPV and IPV “drivers” as well as stigmatize abusers as a deterrent. They should also assist in providing support for victims. People in position of authority/opinion leaders should speak-out and champion positive behavioural change.

At all levels of their development, young people should be taught to have respect for human life and rights to enable them build from violent-free families to violent-free society.

The military community in particular should develop policy and enabling environment for abused women to speak-out and seek redress. Beyond this, the military should also encourage and finance research in the area of studying the effect of military operations and post-traumatic stress disorders on family relationships with a view to developing evidence-based treatment models for military personnel.

Reproductive healthcare providers should be sensitized through advocacy by pressure groups to actively screen every woman accessing healthcare for IPV and treat or refer appropriately.

Government should show more commitment by ensuring speedy passage of the bill on "Elimination of all forms of Violence and Discrimination against Women” which will aid legal process in handling cases of IPV. It should also focus on strategies to ensure the full implementation of the contents of the National Gender Policy which will include programmes that will alleviate poverty and empower women and give them a voice to speak-out and stand up for their human rights. Government should also establish temporary shelters for victims of intimate partner violence. 


\section{Limitations of Study}

The security problem ("Boko Haram scares") in Abuja was a challenge both in the barrack and the civilian communities in gaining access into people's homes. To overcome this, health workers who were involved in the house to house distribution of insecticide treated mosquito nets/polio immunization in FCT were used to facilitate easy access into homes in the study communities.

\section{Conflict of Interest}

The authors declare no potential conflicts of interest with respect to the authorship and/or publication of this article.

\section{References}

Abby, A., Ross, L. T., \& McDuffie, D. (1995). Alcohol's Role in Sexual Assault in RR Watson Editor Drug and Alcohol Reviews: Additive Behaviours in Women. Human Press Totowa, 5, 1-12.

Alabi, T., Bahah, M., \& Alabi, S. O. (2014). The Girl-Child: A Sociological View on the Problems of Girl-Child Education in Nigeria. European Scientific Journal, 10, 393-409. eujournal.org/index.php/esj/article/download/2601/2462

Antalupo, N., Vollendoff, L., Kay, M., \& Shin, P. S. (2006). Domestic Violence in Ghana: The Open Secret. 7 Geo J Gender \& L, 531-597. scholarship.law.georgetown.edu/cgi/viewcontent.cgi?article=1432...

Cone, R. W. (2011). Enduring Attributes of the Profession; Trust, Discipline, Fitness. www.dtic.mil/dtic/tr/fulltext/u2/a570011.pdf

Egyptian National Demographic and Health Survey (2005).

Ellsberg, M. C., Pena-Herrera, A., Liljestrand, J., \& Winkvist, A. (1999). Wife Abuse among Women of Childbearing Age in Nicaragua. American Journal of Public Health, 89, 241-244. http://dx.doi.org/10.2105/AJPH.89.2.241

Harrison, D. (2002). The First Casualty: Violence against Women in Canadian Military Communities. James Lorimer \& Company Ltd., Toronto.

Heyman, R. E., \& Neidig, P. H. (1999). A Comparison of Spousal Aggression Prevalence Rates in U.S. Army and Civilian Representative Samples. Journal of Consulting and Clinical Psychology, 67, 239-242. http://dx.doi.org/10.1037/0022-006X.67.2.239

Hindin, M. J. (2003). Understanding Women's Attitudes towards Wife Beating in Zimbabwe. Bulletin of the World Health Organization, 81, 501-508.

Hurwitz, E. J., Gupta, J., Liu, R., Silverman, J. G., \& Raj, A. (2006). Intimate Partner Violence Associated with Poor Health Outcomes among South Asian Women in US. Journal of Immigrant and Minority Health, 8, 343-364. http://dx.doi.org/10.1007/s10903-006-9330-1

Ijaden, P., \& Theonnes, N. (2000). US Department of Justice: Full Report of the Prevalence, Incidence and Consequences of Violence against Women 2000.

Ilika, A. L. (2005). Women's Perception of Partner Violence in a Rural Igbo Community. African Journal of Reproductive Health, 9, 77-88. http://dx.doi.org/10.2307/3583414

Koenig, M. A., Lutalo, T., Zhao, F., Nalugoda, F., Wabwire-Mangen, F., Kiwanuka, N. et al. (2003). Domestic Violence in Rural Uganda: Evidence from a Community Based Study. Bulletin of the World Health Organization, 81, 50-60.

Odujurin, O. (1999). Wife Battering in Nigeria. International Journal of Gynaecology and Obstetrics, 41, 159-164. http://dx.doi.org/10.1016/0020-7292(93)90699-W

Rabb, K. (2012). A Silent Epidemic: Spousal Abuse is the Military’s Best Kept Secret. http://www.huffingtonpost.com/kim-rabb/best-kept-military-secret_b_1373462.html

Rentz, E. D., Martin, S. L., Gibbs, D. A., Clinton-Sherrod, M., Hardison, J., \& Marshall, S. W. (2006). Family Violence in the Military: A Review of the Literature. Trauma, Violence, \& Abuse, 7, 93-108. http://dx.doi.org/10.1177/1524838005285916

Stamm, S. (2009). Intimate Partner Violence in the Military: Securing Our Country, Starting with the Home. Family Court Review, 47, 321-339. http://dx.doi.org/10.1111/j.1744-1617.2009.01257.x

Subramaniam, P., \& Sivayogan, S. (2001). The Prevalence and Pattern of Wife Beating in the Trincomalee District in Eastern Sri Lanka. The Southeast Asian Journal of Tropical Medicine and Public Health, 32, 186-195.

Swain, R. (2010). The Obligations of Military Professionalism “Service Unsullied by Partisanship”. https://www.mca-marines.org/.../obligations $\% 2$ 
Thurston, W. E., Patten, S., \& Lagendyk, L. E. (2006). Prevalence of Violence against Women Reported in a Rural Health Region. Canadian Journal of Rural Medicine, 11, 259-267.

Valladares, E., Pena, R., Persson, L. A., \& Hogberg, U. (2005). Violence against Pregnant Women: Prevalence and Characteristics. A Population-Based Study in Nicaragua. BJOG: An International Journal of Obstetrics \& Gynaecology, 112, 1243-1248. http://dx.doi.org/10.1111/j.1471-0528.2005.00621.x

Williamson, E. (2011). Domestic Abuse and Military Families: The Problem of Re-Integration and Control. British Journal of Social Work, 2, 12-23.

World Health Organization (2005). WHO Multi-Country Study on Women's Health and Domestic Violence against Women: Initial Results on Prevalence, Health Outcomes and Women's Responses. Geneva.

World Health Organization (2007). Interviewer Training Manual for WHO Multi-Country Study. Geneva. 